\section{Nastamonu Eğitim Dergisi Kastamonu Education Journal}

Kasım 2019 Cilt:27 Sayı:6

kefdergi.kastamonu.edu.tr
Başvuru Tarihi/Received: 04.12.2018

Kabul Tarihi/Accepted: 30.04.2019

DOI: 10.24106/kefdergi.3456

\title{
Okul Öncesi Dönem Çocukların Öz Düzenleme Becerilerinin Annelerine Bağlanma Biçimlerine ve Annelerin Ebeveynlik Davranışlarına Göre İncelenmesi ${ }^{1}$
}

\section{The Investigation of Self-Regulation Skills of Preschoolers According to Their Attachment Styles to Their Mothers and Maternal Parenting Behaviors}

\section{Öz}

\author{
Dilan BAYINDIR ${ }^{2}$, Ozana URAL ${ }^{3}$
}

Öz düzenleme becerileri, akademik başarı ve sosyal yetkinliğin en açık yordayıcılarından biridir. Bu nedenle, bu becerilerin gelişimini etkileyen değişkenlerin belirlenmesi önemlidir. Bu araştırmanın amacı, 60-72 aylık okul öncesi çocukların öz düzenleme becerilerinin annelerine bağlanma biçimlerine göre farklılık gösterip göstermediğini ve annelerinin ebeveynlik davranışları ile çocukların öz düzenleme becerileri arasındaki ilişkiyi incelemektir. Araştrmada tarama yöntemi kullanıımıştı. Örneklem İstanbul'da farklı anaokullarına devam eden 84'ü (\% 49) erkek, 88'i (\% 51) ise kız toplam 172 çocuk ve bu çocukların annelerinden ve öğretmenlerinden oluşmuştur. Veri toplama araçları olarak Öz Düzenleme Becerileri Ölçeği, Oyuncak Öykü Tamamlama Testi ve Çocuk Yetiştirme Anketi kullanılmıştır. Sonuçlar, annelerine güvenli bir şekilde bağlanan çocukların öz düzenleme beceri düzeylerinin güvensiz bağlanan çocuklardan daha yüksek olduğunu göstermektedir. Ayrıca, annelerin itaat bekleyen davranışları ile çocukların öz düzenleme becerileri arasında negatif bir ilişki olduğu tespit edilmiştir. Bulgular, ebeveynlik niteliğinin öz düzenleme becerileri üzerindeki doğrudan ve dolaylı önemini vurgulamaktadır.

Anahtar Kelimeler: öz düzenleme, bağlanma biçimi, ebeveyn davranışları, okul öncesi dönem

\begin{abstract}
The self-regulations skills are one of the most obvious indicators of academic achievement and social competence. For this reason, it is important to determine the variables that affect the development of these skills. The aim of this research is to examine whether the level of self-regulation skills of 60-72 months old preschool children differ according to their attachment styles to their mothers and to investigate the relationship between parenting behaviors of their mothers and self-regulation skills of children. Survey method was used in the study. The sample consists of a total of 172 children, 84 (\%49) of them were boys and 88 (\%51) of them were girls, who attend different preschools in İstanbul and their mothers and preschool teachers. The Self-Regulation Skills Scale, Doll Family Story Completion Test and Parenting Questionnaire were used as data collection tools. The results indicate that self-regulation skill levels of children who are securely attached to their mothers are higher than unsecurely attached children. In addition, it was found that there is a negative relation between self-regulation skills of the children and the mothers'obedience expectation. The findings clearly stress the importance of parenting quality as direct and indirect indicator of self-regulation skills.
\end{abstract}

Keywords: self-regulation, attachment style, parenting behaviors, preschool period

1 This research is a part of a Ph.D. dissertation by Dilan BAYINDIR, who studied at the Educational Sciences Institute of Marmara University. The thesis advisor is Prof. Dr. Ozana URAL.

2 Balıkesir University, Balıkesir, Turkey; https://orcid.org/ 0000-0002-6081-3690

3 Marmara University, İstanbul, Turkey; https://orcid.org/ 0000-0002-5067-3655

Atıf / Citation: Bayındır, D. \& Ural, O. (2019).Okul öncesi dönem çocukların öz düzenleme becerilerinin annelerine bağlanma biçimlerine ve annelerin ebeveynlik davranışlarına göre incelenmesi. Kastamonu Education Journal, 27(4), 2597-2608. doi:10.24106/kefdergi.3456 


\section{Extended Abstract}

Purpose : The mother and child are more interacting and the mother is playing a more active role in child development in Turkish culture. Based on this idea, it is aimed to examine the effects of two maternal considerations on children's self-regulation skills. So, there are two purposes of the study. The first purpose is to examine if the self-regulation skills of preschool children differ according to their attachment styles to their mothers. The second purpose is to investigate if there is a relation between self-regulation skills of preschoolers and their mothers' parenting behaviors.

Method: The study was designed in survey model. Participants in this study were 172 parents, their 60-72 months old preschool-aged children and the teachers of these preschool age children. The Personal Information Form, the Self-Regulation Skills Scale (Bayındır \& Ural, 2016), the Doll Family Story Completion Test (Granot \& Mayseless, 2001; Uluç \& Öktem, 2010) and the Parenting Questionnaire (Sanson 1995 cited in Paterson \& Sanson, 1999; Yağmurlu \& Sanson, 2009) were used as data collection tools. The Personal Information Form and the Parenting Questionnaire were distributed to the mothers through the teachers who volunteered to participate in the research. Forms returned by the mothers after one week. The teachers evaluated self-regulation skills of their students by filling out the Self-Regulation Skills Scale. The Doll Family Story Completion Test was performed with the children of the mothers who completed the forms and allowed the child to participate in the research. The application was carried out by the researchers. Demographic characteristics of the participants were analyzed by descriptive statistical methods. Gender comparison of children's attachment styles was analyzed by the Chi square test. The comparison of children's self-regulatory skill levels according to their attachment styles to their mothers was tested using an independent group t test. Relationships between parenting behaviors and self-regulation skills of children were analyzed by Pearson Moment correlation.

Findings and Comments : The total score and regulation skills subscale scores of the securely attached children was found to be higher than children who insecurely attached. Similarly the related literature indicate positive relation between secure attachment style and emotion regulation (Gilliam, Shaw, Beck, Schonberg \& Lukon, 2002; Kliewer, Fearnow \& Miler, 1996; Uluç \& Öktem, 2010; Ural et al., 2015), attention (Granot \& Mayseless, 2001; Moss \& St-Laurent, 2001; O'Connor \& McCartney, 2007), mental performance (West, Brittany\& Kerns, 2013) and self-motivation (van ljzendoorn, Dijkstra \& Bus, 1995).

The relation between children's self-regulation skills and their parents' parenting behaviors were analyzed by Pearson moment correlation analysis. As can be seen, only obedience behavior of parents was found significantly related with self-regulation skills of children and the direction of the relation was negative. The children of parents who expect more obedience from their children, indicate low levels of self-regulation behaviors. It could be stated the finding is parallel to the view that is over controlling parenting behaviors can be harmful to children (Sturge-Apple et al. 2012). The results of a research show that over controlling parenting has a negative effect on the effortful control skills of children (Taylor et al. 2013). Similarly, another finding states that negative parental control can prevent the development of attention and cognitive processes (Grusec \& Goodnow, 1994).

Suggestions : The findings of the present study suggest that parenting behaviors are associated with the extend of children's self-regulation skills directly and through the attachment pattern. There are several important implications that can be drawn from these findings. According to Bandura's social cognitive theory, self-regulation begins to develop in social interaction and becomes internalized over time (Schunk \& Zimmerman, 1997). By considering the important effect of the parenting behaviors, the quality of these behaviors should be supported through different intervention ways such as parent trainings, ensuring environmental support opportunities as economic support or workplace support. Also, these interventions should be applied as early as possible by considering the importance of early caregiving on child development. 


\section{Introduction}

In preschool period, children begin to direct behavior, feelings and thoughts to reach the goals they set for themselves and use mental strategies to control these elements. These skills are the highest-level skills expected to be earned in the preschool period and are called self-regulation skills.

Many different theoretical approaches such as behaviorist, social cognitive, information processing, social cultural approach define the concept of self-regulation differently. Self-regulation is a multidimensional concept involving the regulation and control of emotion, behavior, attention and motivation and all these dimensions develeop by interacting with each other (Kopp, 1982). In other words, self-regulation means planned and systematic feelings, thoughts and behaviors that the individual exhibits to achieve a certain purpose by taking advantage of cognitive, metacognitive and motivational strategies (Schunk, 2001). Concepts such as metacognition (Whitebread et al., 2009), executive functions (Bryce, Whitebread \& Szüer, 2014), effortful control (Eisenberg et al., 2010) are thought to be synonymous or part of the concept of self-regulation. Metacognitive functions such as planning, monitoring, control and evaluation skills (Whitebread et al., 2009); emotion and motivational regulation (Schraw, Crippen \& Hartley, 2006; Whitebread et al., 2009); inhibitory control (Eisenberg, et al., 2010; McCelland, Cameron, Conor, Farris, Jewkes \& Morrison, 2007) and attention control skills (Eisenberg et al., 2010; Kochanska, Murray \& Harlan, 2000) are the ones defined as a component of this concept.

These skills are related to social and moral competence (Kochanska et al., 2000; Kochanska, Murray, Jacques, Koenig \& Vandegeest, 1996), peer relationships (Ramani, Brownell \& Campbell, 2010), emotional regulation (Carlson \& Wang, 2007; Simonds, Kieras, Rueda \& Rothbart, 2007), psychological well-being (Eisenberg et al., 2004), school achievement (Blair, 2002; Blair \& Diamond, 2008; Ponitz, McChelland, Jewkes, Connor, Farris \& Morrsion, 2008) and effective classroom behavior (Ponitz et al., 2008). These important skills needs to be investigated in terms of their origins. This study examines attachment security and parenting behaviors as factors contribute to the formation of these skills.

\section{The attachment style as a predictive factor of self regulation skills}

The relationship between attachment and self-regulation skills can be discussed in two dimensions through the effects of mental representations developed by children and the effects of parents. Bowlby (1969) points out that the relationship with the caregiver leads to the formation of children's mental representations both for themselves and for their environment. The mental schemes that babies make about themselves and others are affected by the attachment pattern between the caregiver and the baby. Babies internalize these mental schemes and these schemes play a major role in the formation of self-perceptions (Bretherton, 1992). If the caregiver meets the needs of the child, the child perceived himself/herself valued. The baby takes action to discover the environment and this based on the meet of the needs' of the baby by her/his mother or caregiver (Bowlby, 1969). According to this view, the source of motivation for discovering and learning the environment is in proportion to meeting these needs. For this reason, the mode of secure attachment is a predictor of the autonomy of the child (Van ljzenndoor \& Sagi, 2005 cited in Kağıtçıbaşı, 2010). However, negative attachment experiences cause the child's mind not to work sufficiently integrated (Siegel, 2001). According to this view, the child who indicates insecure attachment style cannot approach the environment safely and it is difficult to understand the stimuli that surround him because of the high level of anxiety s/he shows.

The second dimension is parental characteristics. Parents support the development of the child's self-regulation skills by guiding the rhythm and feelings of the baby as external regulators (Kopp, 1982). Mothers of securely attached children are more sensitive to the needs of children (Ainsworth, Bell \& Stayton, 1971 cited in Meins, Fernyhough \& Russell, 1998) and parental behaviors of these mothers are more consistent (Isabella, 1993). Ainsworth and her colleagues (1971, cited in Meins et al., 1998) indicated that mothers of securely attached children are more likely to look at events from their child's point of view, respect children as individuals, and do not show negative behaviors during activities. Also, these mothers of securely attached children provide higher quality support during their learning tasks (Dubois-Comtois, Cyr \& Moss, 2011).

Kopp (1982) explains the effect of attachment security on self-regulation skills of children through the ability children gain to control their reactions during the attachment process. Similarly, Vaugh, Egeland, Srougers and Waters (1979) indicate that securely attached infants are more resistant, self-controlled and more curious in the preschool period. The high level of control skills of children can be an integrated work of mind away from anxiety and insecurity. The literature in Turkey points to similar points. For example, Uluç and Öktem (2010) showed that attachment security is related to impulse control. 
The results of a study done by Pearson (2013) showed that securely attached preschool age children get higher scores on measures assess emotional, behavioral and cognitive regulation skills than children who are attached insecurely. West, Brittany, and Kerns (2013) explain the relation between attachment and mental performance through attention control. According to them, secure attachment leads to the development of attentional skills. There are also other studies suggesting that attention skills are related to attachment (Granot \& Mayseless, 2001; Moss \& St-Laurent, 2001; O'Connor \& McCartney, 2007). Similarly, van IJzendoorn, Dijkstra and Bus (1995) indirectly relate the attachment style and academic achievement. In their view, attachment style indirectly mediates academic success by influencing children's self-motivation and self-control. According to this view, it is important that the child is able to organize his/ her own motivation without any external supervision for behavior regulation. The findings of studies that investigated the relationship between the different components of self-regulation and attachment styles also point to the fact that securely-attached children generally use more effective self-regulation skills.

\section{Parenting behaviors as a predictive factor of self regulation skills}

Parenting is considered as a predictive factor of self-regulation skills of children (Kochanska, Murray \& Harlan, 2000; Olson, Bates, Sandy \& Schilling, 2002). According to Glaser (2000) the development of the frontal brain responsible for executive functions depends on the nature of the interaction with the caregiver. In young children, the central social environment is often defined in interaction with a parent or care. In the case of this type of interaction, the parents support them to acquire the knowledge and skills that will help them to act independently (Wertsch, McNamee, McLane \& Budwig, 1980). Support is defined as allowing children to take responsibility for tasks on their capacities and to allow them to progress on topics that they can progress independently (Wood, Bruner \& Ross, 1976). In other words, it is the ability of parents to provide or withdraw help depending on the level of child achievement. The support that parents provide in problem solving tasks is positively associated with children's subsequent performance in similar activities and independent achievement (Mattanah, Pratt, Cowan \& Cowan, 2005; Pratt, Green, MacVicar \& Bountrogianni, 1992; Pratt, Kerig, Cowan \& Cowan, 1988). With parental guidance, children learn which elements of the environment they need to be aware of. This support or "regulation by others" can lead to a transition from other-regulation to self-regulation in independent tasks (Rogoff, Mistry, Goncu \& Mosier, 1993 cited in Harris, Robinson, Chang \& Burns, 2007).

The literature survey conducted by Pino-Pasternak and Whitebread (2010) showed that three parenting dimensions (challenge, autonomy and contingency) and six parenting behaviors (metacognitive talk, active participation, understanding of control, shifts in responsibility, emotional responsiveness and contingent instructional scaffolds) are associated with motivational and metacognitive behaviors. Because of the rich literacy on parenting dimensions, there are different terms, like the ones mentioned above, that contribute to similar concepts. The dimensions are discussed as named by different researchers below.

Carlson (2003, cited in Bernier, Carlson \& Whipple, 2010) states that three parenting dimensions affect the child's ability of executive functioning. These dimensions are maternal sensitivity, scaffolding and mind-mindedness. Sensitivity involves giving appropriate and consistent responses to the baby's messages. Scaffolding means offering problem-solving skills appropriate for the child's age. The mind-mindedness means parents tend to use mental terms while talking to children. In this way, the child may be directed from being externally regulation to self-regulation. Bernier and his colleagues (2010) investigated the relationship between parent-child interaction quality and children's executive functions (working memory, impulse control and set shifting) skill levels. Unlike the survey described above, the influence of the level of mothers' support for children's autonomy has also been examined. Three parenting dimensions (maternal sensitivity, mind-mindedness and autonomy support) have been found to be related to the executive functioning skills in children. It has been found that autonomy support is the strongest predictor of executive functions, independent of mother education and general cognitive skills. These results support the view that the quality of early child-parent / caregiver relationship improves children's self-regulation skills.

In early childhood, hypercontrolled parenting can be harmful (Sturge-Apple, Davies, Martin, Cicchetti, \& Hentges, 2012). When parents display unrelated, insensitive, and punitive behaviors, the self-regulation skills of children are negatively affected (Eisenberg et al., 2010). For example, negative parental control can damage the development of attention and cognitive processes (Grusec \& Goodnow, 1994). As insensitive or over controlling parents can undermine the development of independent coping skills and independent behavior in children, sensitive parents may be models of effective coping skills, providing appropriate support when children are challenged (Power, 2004). 
Pino Pasternak and Whitebread (2010) emphasize that parental control influences not only the development of metacognitive skills, but also the motivational dimension of self-regulation. Inadequate parental control not only limits children's opportunities for independent discovery and participation in mental tasks, but also influences children's understanding of control resources and leads them to examples of external motivation. Research on motivation for children from low-income families has shown that these children are more likely to need external assistance, have a shorter duration of duty, have more task-related negative situations, and are more likely to give up when they meet with difficulties (Malakoff, Underhill \& Zigler 1998; Turner \& Johnson, 2003).

Kochanska and her colleagues (2000) show that maternal acceptance level, support and warmth predict effortful control skills of infants at the age of 22 months and 33 months. Similarly, a study done by Eisenberg and her colleagues (2005) showed that parental warmth/positive expressivity of parents predicted children's effortful control skills. The findings of Zhou, Eisenberg, Wang and Reiser (2004) demonstrate the same that authoritarian parenting associate with low effortful control. A study of Taylor, Eisenberg, Spinrad and Luidaman (2013) on ego resiliency, effortful control and parental behavior shows that intrusive parenting negatively predicts effortful control skills of children. The results show that negative parenting has negative effects on children's ego resiliency due to the negative effects on children's attention and behavior regulation. There are researchers who argue that attention regulation can be related to ego resiliency as it relates to both managing negative emotions and sustaining coping strategies (Derryberry \& Reed, 1996; Lengua, Sandler, West, Wolchik \& Curran, 1999; Rothbart, Ahadi \& Evans, 2000).

Even temperament characteristics, related with self-regulation, can be shaped by parental behaviors. For example, although inhibitory-control is considered a temperament trait, research findings indicate that adult interaction is effective on this skill. The positive support given to babies by their parents at the age of 2 supports the formation of inhibitory-control skills that develop between the ages of 2 and 4 (Moilanen, Show, Dishion, Gardner \& Wilson, 2010).

As can be seen above, different concepts related to self-regulation are associated with parenting behaviors. For example executive functions (Bernier et al., 2010), effortful control (Eisenberg et al., 2005; Kochanska et al., 2000; Taylor, Eisenberg, Spinrad \& Luidaman, 2013; Zhou, Eisenberg, Wang \& Reiser, 2004), metacognition (Pino Pasternak \& Whitebread, 2010), motivational regulation (Harris et al., 2007; Pino Pasternak \& Whitebread, 2010), attention regulation (Grusec \& Goodnow, 1994), inhibitory control (Greenberg, 2006; Moilanen et al. 2010) and emotion regulation (Altan, 2006; Metin, 2010; Fox \& Calkins, 2003; Morris, Silk, Steinberg, Myers \& Robinson, 2007) are found in relation with parenting behaviors.

\section{The purpose of the study}

The first purpose of this study is to examine if the self-regulation skills of preschool children differ according to their attachment styles to their mothers. The second purpose of the study is to investigate if there is a relation between self-regulation skills of preschoolers and their mothers' parenting behaviors. It is assumed that the mother and child are more interacting and the mother is playing a more active role in child development in Turkish culture duty traditional gender roles (Kağıtçıbaşı, 2007), low rate of female employment (OECD, 2011) and low rate of preschool education. Based on this assumption, it is aimed to examine the effects of parental behaviors of mothers and attachment status of preschool children to their mothers on children's self-regulation skills.

\section{Method}

\section{Research Design}

The study was designed in survey model. The survey model requires observation of what naturally goes on in the world to see the relationships between naturally-occurring variables without interfering directly (Field, 2005).

\section{Research Sample}

Participants in this study were 172 parents, their 60-72 months old preschool-aged children who attend preschools in İstanbul and the teachers of these preschool age children. Although $84(49 \%)$ of the children participated in the research were boys and their average age was 67.21 ( \pm 3.76$)$ months, $88(51 \%)$ were girls and their average age was $66.57( \pm 3.92)$ months.

$6(3.7 \%)$ of the mothers who participated in the study were illiterate, $44(26.8 \%)$ of them were primary school, 26 (15.9\%) were middle school, 46 (28\%) were high school, $42(25.6 \%)$ are university graduates. Although the number of single mothers were $6(3.5 \%)$, the number of married ones was 165 (96.5\%). 23 (14.1\%) of them stated that their in- 
come was low, $133(77.3 \%)$ of them stated as moderate and $7(4.1 \%)$ of them stated as high. 11 (6.4\%) mothers were part-time worker, 50 (29.2\%) of them were full-time worker and $109(63.7 \%)$ of them were not working. The average age of the participant mothers was 33.93 .

The total number of participant teachers is 11 and all of these teachers work in public schools. The average age of the participant teachers was 42.7. The teaching experiences of them change from 5 to 26 years.

\section{Data Collection Tools}

Within the scope of the research, the tools used for data collection were the Personal Information Form, the Self-Regulation Skills Scale, the Doll Family Story Completion Test and the Parenting Questionnaire.

Personal Information Form: This form was developed by the researcher and it has been used to obtain demographic information about the mothers and children in the study group. In the form, there are a total of 12 questions about the child's age, gender, schooling year and family (parental age, education status, working status, marital status, income level). The form was delivered to the mothers with the help of the teachers and collected back.

Self-Regulation Skills Scale (SRSS): The scale, that was developed by Bayındır and Ural (2016) in Turkish, consisting of 33 items assesses self-regulation skill levels of preschool children aged between 48-72 months. In each item, the teacher assesses the child's self-regulation skill level based on the likert type score of 5 . The scale is composed of 2 subscales named as regulation (21 items) and control skills (12 items). "S/he sets goals for her/himself (for example, $\mathrm{s} /$ he tells or indicates $\mathrm{s} / \mathrm{he}$ will build a tower in her/his length before he starts building the tower)" is an example of regulation subscale items. One item example from the control subscale skills scale is "S/he could shift her/his attention when passing from one activity to another". The Cronbach's Alpha value of the total scale was found to be .96. The Cronbach Alfa values of each subscales scale were found as .96 for regulation and .91 for control skills. The test-retest value was calculated as 99 .

The Doll Family Story Completion Test TR (DFSCT-TR): The Doll Family Story Completion Task was developed by Granot and Mayseless (2001). The scale was developed on the basis of the storytelling technique developed by Bretherton and his colleagues (Uluç \& Öktem, 2010). Short narratives initiated by the practitioner are completed by the child. In doing so, the child uses dolls and toy items. It is accepted that the child identifies with the child doll in the story and the way s/he completes the stories indicate her/his attachment style. The scale consists of a total of 6 stories including the story of warming. The warm-up story is not included in the score. The order of story themes are as follows: (1) the child pours the juice at the breakfast table; (2) falls off from rock during a trip in the park; (3) is afraid when s/he goes to bed to sleep; (4) the parent leaves the child at home with the caregiver for a period of time; (5) the child and the parent reunite. Four criteria are taken into consideration during encoding: (1) clear expressions of emotions (2) the nature of the parent-child relationship (eg, parental sensitivity and responsiveness level), (3) positive solution of the conflict in the story and (4) consistency of the child's transfer with the story content. The number of unsecure transfers of the child is taken into consideration. If the child transfers three or more unsecure stories, than it is accepted the child insecurely attached to her/his mother. The interrater coefficient score between two judges for the final classification was found as .91. This score change between .78 to .85 for each separate story (Granot \& Mayeseless, 2001). The scale was adapted into Turkish by Uluç in 2005 (Uluç \& Öktem, 2010). The interrater reliability coefficient is 83 for the general classification of the Turkish form and it changes between .81 to 1.00 for each stories (Uluç, 2005 cited in Güner Algan \& Şendil, 2013). This scale was applied with children individually by the researcher. The average duration of the application with each child is 40 minutes.

Parenting Questionnaire (PQ): The Parenting Questionnaire that is used to measure parenting behaviors, was developed by Sanson (1995 cited in Paterson \& Sanson, 1999). It includes 30 items. In each item, the parents evaluate the frequency of their parenting behavior based on the likert type score of 5 . There are totally 4 subscales named as obedience, punishment, warmth and inductive reasoning. There are same examples of items under these four subscales; Obedience (e.g., "I expect my child to do what he/she is told to do, without stopping to argue about it."), Punishment (e.g., "I use physical punishment, e.g., smacking, for very bad behaviour."), Warmth (e.g., "My child and I have warm, intimate times together."), Inductive Reasoning (e.g., "I try to explain to my child why certain things are necessary."). It was adapted to Turkish by Yağmurlu and Sanson (2009). The Turkish form of the questionnaire consists of 30 items as in the original. The Cronbach Alfa values of each subscales of the Turkish form were found as .78 for obedience, .84 for punishment, .68 for warmth and .76 for inductive reasoning for the Turkish sample (Yağmurlu \& Sanson, 2009). This scale was delivered to the mothers with the help of the teachers. 


\section{Data Collection}

First of all, necessary permission was obtained from the relevant researchers for the use of the data collection tools. Subsequently, the toy materials required for the Doll Family Story Completion Test were provided. After obtaining permission from Istanbul Ministry of Education, randomly selected school administrators and teachers were informed about the research process. The lists of students were taken from the voluntary schools and an identification number were given to each student.

The Personal Information Form and the Parenting Questionnaire were distributed to the mothers through the teachers who volunteered to participate in the research. The forms were given to the mothers in a closed envelope, and the envelope was collected back as closed. Forms returned by the mothers after 1 week. The teachers evaluated self-regulation skills of their students by filling out Self-Regulation Skills Scale. The Doll Family Story Completion Test was performed with the children of the mothers who completed the forms and allowed the child to participate in the research. The application was carried out by the researchers. Practices were carried out on the days and hours determined together with the class teachers. The practices were conducted individually in an isolated room provided by the institutions in which the children were attended. After each application, time is allocated for scoring. At the end of each practice, participants are entitled to select a small toy from the toy box. On special days of activities and celebrations, children are not taken from the group, and if necessary, their appointments are canceled.

By giving the identification number for each child, the data collected from children, their mothers and teachers are archived using these numbers. After the applications are completed, all the forms are examined and the forms that do not match and the ones that include missing information were excluded from the analysis. The obtained data was transferred to the appropriate statistical package program.

\section{Data Analysis}

The data was analyzed with version 21 of Statistics for Social Sciences (SPSS). Demographic characteristics of the participants were analyzed by descriptive statistical methods. Gender comparison of children's attachment styles was analyzed by the Chi square test. The comparison of children's self-regulatory skill levels according to their attachment styles to their mothers was tested using an independent group t test. Relationships between parenting behaviors and self-regulation skills of children were analyzed by Pearson Moment correlation.

\section{Results}

According to the Doll Family Story Completion Test results, 139 (80.8\%) of the children were found to be attached securely to their mothers and 33 (19.2\%) were found to be attached insecurely. It has been analyzed whether the attachment patterns of children participating in the research differ according to gender by chi-square analysis. The results of this analysis are presented in Table 1 below.

Table 1. The results of chi-square analysis on the distribution of children according to gender

\begin{tabular}{|c|c|c|c|c|c|c|c|c|}
\hline & & & oys & & Girls & $x^{2}$ & sd & $\mathbf{p}$ \\
\hline Attachment style & $\begin{array}{l}\text { Secure } \\
\text { Insecure }\end{array}$ & $\begin{array}{l}n=67 \\
n=18\end{array}$ & $\begin{array}{l}78.8 \% \\
21.2 \%\end{array}$ & $\begin{array}{l}n=72 \\
n=15\end{array}$ & $\begin{array}{c}82.8 \% \\
17.2 \%\end{array}$ & .429 & 1 & .512 \\
\hline
\end{tabular}

The distribution of children's attachment styles by gender was not statistically significant. T test analysis was used to test whether their self-regulatory skills levels change according to children's attachment styles by independent t test analysis. The obtained data is shown in the table below.

Table 2. Independent group t test analysis results on comparing self-regulation skill levels according to attachment styles

\begin{tabular}{|c|c|c|c|c|c|c|c|}
\hline & Attac & nt Style & $\overline{\mathrm{X}}$ & ss & sd & $\mathbf{t}$ & $\mathbf{P}$ \\
\hline \multirow{2}{*}{ Total } & Secure & $(n=139)$ & 3.70 & 0.38 & \multirow{2}{*}{170} & \multirow{2}{*}{3.295} & \multirow{2}{*}{.001} \\
\hline & Insecure & $(n=33)$ & 3.44 & 0.48 & & & \\
\hline \multirow{2}{*}{ Regulation Skills } & Secure & $(n=139)$ & 4.09 & 0.57 & \multirow{2}{*}{170} & \multirow{2}{*}{3.955} & \multirow{2}{*}{.000} \\
\hline & Insecure & $(n=33)$ & 3.63 & 0.71 & & & \\
\hline \multirow{2}{*}{ Control Skills } & Secure & $(n=139)$ & 3.04 & 0.39 & \multirow{2}{*}{170} & \multirow{2}{*}{1.339} & \multirow{2}{*}{.182} \\
\hline & Insecure & $(n=33)$ & 3.14 & 0.37 & & & \\
\hline
\end{tabular}


The total score $(t(170)=3.295, p=.001)$ and regulation skills subscale scores $(t(170)=3955, p=.000)$ of the securely attached children was found to be higher than children who insecurely attached. No significant difference was found between the control subscale scores of securely and insecurely attached children $(t(170)=-1.339, p=.182)$.

Table 3. Correlation results on relationship between parental behaviors and children's self-regulation skills

\begin{tabular}{lcccc}
\hline \multicolumn{1}{c}{ PB } & Obedience & Punishment & Warmth & Inductive Reasoning \\
\hline 1.Total (SR) & $-.17^{*}$ & -.05 & -.12 & -.04 \\
2.Regulation Skills (SR) & $-.18^{*}$ & -.04 & -.13 & -.08 \\
3.Control Skills (SR) & -.02 & -.01 & .02 & .09 \\
\hline
\end{tabular}

Note. $\mathrm{SR}=$ children's self-regulation scores, $\mathrm{PB}=$ Parenting Behaviors $* \mathrm{p}<.05$

The relation between children's self-regulation skills and their parents' parenting behaviors were analyzed by Pearson moment correlation analysis. As can be seen, only obedience behavior of parents was found significantly related with self-regulation skills of children and the direction of the relation was negative. The children, of parents who expect more obedience from their children, indicate low levels of self-regulation behaviors.

\section{Discussion and Conclusion}

The first aim of the study was to examine if the self-regulation skill levels of preschool children differ according to their attachment styles to their mothers. It was found that $80.8 \%$ of the children were securely attached to their mothers and $19.2 \%$ of the children showed insecure attachment to their mothers. Research shows that the form of secure attachment is more common (Madigan, Bakermans-Kranenburg, Van ljzendoorn, Moran, Pederson \& Benoit, 2006). This result also coincides with the results of the research done with preschool children in Turkey by using Doll Family Story Completion Test. The related research states the rate of securely attached ones differs from $88 \%$ (Güner-Algan \& Şendil, 2013), 75\% (Uluç \& Öktem, 2009) and 67.9\% (Ural, Güven, Sezer, Efe-Azkeskin \& Yılmaz, 2015) in different studies.

It was found that the attachment styles of the children participating in the study did not show any significant difference according to gender. There are studies showing that the attachment styles of a child differ according to gender (Chen, 2012; Szewczyk-Sokolowsky, Bost \& Wainwright, 2005; Güner, 2011), in favor of girls (Görgü, 2015) and also in favor of boys (Ural et al., 2015). However, some other studies indicate no difference (ilaslan, 2009; Sözügeçer, 2011). The reason behind these different findings may be characteristics of the study groups.

When the relationship between attachment styles and self-regulation skills was examined, it was found that children with secure attachment showed higher self-regulation skills in the total score and regulation subscale than children with insecure attachment style. Similarly the related literature indicate positive relation between secure attachment style and emotion regulation (Gilliam, Shaw, Beck, Schonberg \& Lukon, 2002; Kliewer, Fearnow \& Miler, 1996; Uluç \& Öktem, 2010; Ural et al., 2015), attention (Granot \& Mayseless, 2001; Moss \& St-Laurent, 2001; O'Connor \& McCartney, 2007), mental performance (West, Brittany \& Kerns, 2013) and self-motivation (van ljzendoorn, Dijkstra \& Bus, 1995). There were no significant differences in control subscale score between different attached children. However, there are study findings indicate attachment security support self-control (van ljzendoorn, Dijkstra \& Bus, 1995) and control of mental skills (Meins et al., 1998). The reason of no significant relation between the control subscale score of children and attachment styles could be explained by considering that control dimension is more about temperamental considerations and the rate of secure attachment is same for children with any type of temperament (Mangelsdorf, Shapiro \& Marzolf, 1995).

The second aim of the study is to investigate if there is a significant relation between the self-regulation of children and the parenting behaviors of their mothers. When we examine the relationship between self-regulation skills of children and child-rearing behaviors of mothers, it is found that there is a significant relationship between only the "obedience" subscale of the Parenting Questionnaire and the total score and regulation subscale scores of Self-Regulation Skills Scale. The finding of negative relationship, between the "obedience" subscale and self-regulation skills, overlaps with the literature. It could be stated the finding is parallel to the view that is over controlling parenting behaviors can be harmful to children (Sturge-Apple et al. 2012). The results of a research show that over controlling parenting has a negative effect on the effortful control skills of children (Taylor et al. 2013). Similarly, another finding states that negative parental control can prevent the development of attention and cognitive processes (Grusec \& Goodnow, 1994).

| Kastamonu Eğitim Dergisi, 27(6), 2019| 
According to the results of the analysis, the relationship between punishment and self-regulation skills in children is negative, though not significant. This finding can be considered to be parallel to the view that the self-regulation skills of the children will be adversely affected by their punitive behavior of parents (Eisenberg et al., 2010).

Although the relation between the Parenting Questionnaire's warmth and inductive reasoning subscales and total score and regulation subscale of the Self-Regulation Skills Scale were not significant, the direction is negative. By referring to the findings of previous studies that indicate maternal sensitivity, scaffolding, mind-mindedness and autonomy support improve executive functioning skills of young children (Bernier et al., 2010) then the negative relation could be stated as a finding to be questioned. Similarly, Denham, Renwick and Holt (1991) indicate high levels of mindfulness and warmth and low levels of obedience and punishment predict emotion regulation skills that is a subdomain of self-regulation. This result could be occurred because of cultural differences on definition and practices of parenting behaviors. This finding is an important one to cite because it could lead to further studies to examine the relation.

This research is important for examining the relationship between self-regulating skill levels and attachment security of preschool children who are not often studied due to methodological difficulties. Also, the study's data on children's attachment security is based on children's stories. However, because this application procedure takes long time to apply, this limited the number of sample. Another limitation of the study is that parenting behaviors of mothers are based on self-assessments. Further studies could focus on other assessment ways to determine the parenting behaviors.

The findings of the present study suggest that parenting behaviors are associated with the extend of children's self-regulation skills directly and through the attachment pattern. There are several important implications that can be drawn from these findings. According to Bandura's social cognitive theory, self-regulation begins to develop in social interaction and becomes internalized over time (Schunk \& Zimmerman, 1997). By considering the important effect of the parenting behaviors, the quality of these behaviors should be supported through different intervention ways such as parent trainings, ensuring environmental support opportunities as economic support or workplace support. Also, these interventions should be applied as early as possible by considering the importance of early caregiving on child development.

\section{References}

Altan, Ö. (2006). The effects of maternal socialization and temperament on children's emotion regulation. (Unpublished master thesis). Koç University Social Sciences Institude, İstanbul, Turkey.

Bayındır, D. \& O. Ural. (2016). Öz Düzenleme Becerileri Ölçeği'nin geliştirilmesi [Development of the Self-Regulation Skills Scale]. International Online Journal of Educational Sciences, 8, 119-132. http://dx.doi.org/10.15345/iojes.2016.04.011

Bernier, A., Carlson, S.M. \& Whipple, N. (2010). From external regulation to self regulation: Early parenting precursors of young children's executive functions. Child Development, 81, 326-339. https://doi.org/10.1111/j.1467-8624.2009.01397.x

Blair, C. (2002). School Readiness: Integrating cognition and emotion in a neurobiological conceptualization of children's functioning at school entry. American Psychologist, 57(2), 111-127. http://dx.doi.org/10.1037/0003-066X.57.2.111

Blair, C. \& Diamond, A. (2008). Biological processes in prevention and intervention: The promotion of self-regulation as a means of preventing school failure. Development and Psychopathology, 20 (3), 899-911. https://doi.org/10.1017/S0954579408000436

Bretherton, I. (1992). The origins of attachment theory: John Bowlby and Mary Ainsworth. Developmental Psychology, 28 (5), 759-775.

Bryce, D., Whitebread, D. \& Szüer, D. (2015). The relationship among executive functions, metacognitive skills and educational achievement in 5 and 7 year old children. Metacognition Learning, 10(2), 181-198. https://doi.org/10.1007/s11409-014-9120-4

Bowly, J. (1969). Attachment and Loss, New York: Basic Books.

Carlson, S. M. \& Wang, T.S. (2007). Inhibitory control and emotion regulation in preschool children. Cognitive Development, 22(4), 489-510. https://doi.org/10.1016/j.cogdev.2007.08.002

Chen, B. (2012). The associations between self-reported mother-child attachment and social initiative and withdrawal in Chinese school-aged children. The Journal of Genetic Psychology: Research and Theory on Human Development, 173 (3), $279-301$. https://doi.org/10.1080/00221325.2011.609847

Denham, S. A., Renwicki, S. M. \& Holt, R. W. (1991). Working and playing together: Prediction of preschool social-emotional competence from mother child interaction. Child Development, 62 (2), 242-249. https://doi.org/10.1111/j.1467-8624.1991.tb01528.x

Derryberry, D. \& Reed, M. A.. (1996). Regulatory processes and the development of cognitive representations. Development and Psychopathology, 8 (1), 215-234. https://doi.org/10.1017/S0954579400007057

Dubois-Comtois, K., Cyr, C. \& Moss. E. (2011). Attachment behavior and mother-child conversations as predictors of attachment representation in middle childhood: A longitudinal study. Attachment and Human Development, 13(4), 335-357. https://doi. org/10.1080/14616734.2011.584455

| Kastamonu Eğitim Dergisi, 27(6), 2019| 
Eisenberg, N., Haugen, R. Spinrad, T. L. Hofer, C. Chassin, L. \& Zhou, Q. (2010). Relations of temperament to maladjustment and ego-resiliency in at-risk children. Social Development, 19 (3), 577-600. https://doi.org/10.1111/j.1467-9507.2009.00550.x

Eisenberg, N., Zhou, Q., Spinrad, T. L., Valiente, C., Fabes, R. A. \& Liew, J. (2005). Relations among positive parenting, children's effortful control, and externalizing problems: A three-wave longitudinal study. Child Development, 76 (5), 1055-1071. https:// doi.org/10.1111/j.1467-8624.2005.00897.x

Eisenberg, N., Spinrad, T. L. Fabes, R. A. Reiser, M. Cumberland, A. Shepard, S. A., Valiente, C., Losoya S. H., Guthrie, I. K. \& Thompson, M.. (2004). The relations of effortful control and impulsivity to children's resiliency and adjustment. Child Development, 75 (1), 25-46. https://doi.org/10.1111/j.1467-8624.2004.00652.x

Field, A. (2005). Discovering statistics using SPSS. Third Edition. SAGE: London.

Fox, N. A. \& Calkins, S. D. (2003). The development of self-control of emotion: Intrinsic and extrinsic influences. Motivation and Emotion, 27 (1), 7-26. https://doi.org/10.1023/A:1023622324898

Gilliom, M., Shaw, D. S., Beck, J. E., Schonberg, M. A. \& Lukon J. L. (2002). Anger regulation in disadvantaged preschool boys: Strategies, antecedents, and the development of self-control. Developmental Psychology, 38 (2), 222-235.

Glaser, D. (2000). Child abuse and neglect and the brain: A review. Journal of Child Psychology and Psychiatry, 41 (1), $97-116$.

Granot, D. \& Mayseless, O. (2001). Attachment security and adjustment to school in middle childhood. International Journal of Behavioral Development, 25 (6), 530-541. https://doi.org/ 10.1080/01650250042000366

Greenberg, M. T. (2006). Promoting resilience in children and youth: Preventive interventions and their interface with neuroscience. Annals New York Academy of Sciences, 1094 (1), 139-150. https://doi.org/10.1196/annals.1376.013

Grusec, J. E. \& Goodnow, J. J. (1994). Impact of parental discipline methods on the child's internalization of values: A reconceptualization of current points of view. Developmental Psychology, 30 (1), 4-19. http://dx.doi.org/10.1037/0012-1649.30.1.4

Görgü, E. (2015). Okula devam eden 5-6 yaş grubu çocukların bağlanma biçimleri ve sosyal davranışları ile annelerin bağlanma biçimi ve kişilik özellikleri arasındaki ilişkinin incelenmesi [A study on the relationship between attachment styles and social behaviors of school children aged 5-6, and the attachment styles and personality traits of their mothers]. (Unpublished doctoral dissertation). Marmara University Educational Sciences Institude, İstanbul, Turkey.

Güner, A. (2011). Okul öncesi çocuklar ve ebeveynlerinin bağlanma güvenlikleri ile çocuk yetiştirme tutumları arasındaki ilişkilerin incelenmesi [The investigation of relations among parents' and preschool children's attachment security and child rearing attitudes]. (Unpublished master thesis), İstanbul University, İstanbul, Turkey.

Güner Algan, A. \& Şendil, G. (2013). Okul öncesi çocuklar ve ebeveynlerinin bağlanma güvenlikleri ile çocuk yetiştirme tutumları arasındaki ilişkiler [The relations among parents' and preschool children's attachment security and child rearing attitudes]. Studies in Psychology, 33 (1), 55-68.

Harris, R.C., Robinson, J. B., Chang, F. \& Burns, B. M. (2007). Characterizing preschool children's attention regulation in parent-child interactions: The role of effortful control and motivation. Journal of Applied Developmental Psychology, 28 (1), 25-39. https:// doi.org/10.1016/j.appdev.2006.10.006

Isabella, R. A. (1993). Origins of attachment: Maternal interactive behavior across the first year. Child Development, 64 (2), 605621. https://doi.org/10.1111/j.1467-8624.1993.tb02931.x

İlaslan, Ö. (2009). Çocukların bağlanma davranışlarının özlük nitelikler ve anne bağlanma stillerine göre incelenmesi [Examining childrens' attachment behaviors according to personal qualities and mothers' attachment styles]. (Unpublished doctoral dissertation). Selçuk University, Konya, Turkey.

Kağıtçıbaşı, Ç. (2010). Benlik, Aile ve Insan Gelişimi: Kültürel Psikoloji [Identity, Family and Human Development: Cultural Psychology]. İstanbul: Koç University Press.

Kağıtçıbaşı, Ç. (2007). Family, self, and human development across cultures: Theory and applications (2nd ed.). London: Lawrence Erlbaum.

Kliewer, W., Fearnow, M. D. \& Miller, P. A. (1996). Coping socialization in middle childhood: Tests of maternal and paternal influences. Child Development, 67 (5), 2339-2357. https://doi.org/10.1111/j.1467-8624.1996.tb01861.x

Kochanska, G., Murray, K. T. \& Harlan E. T. (2000). Effortful control in early childhood: Continuity and change, antecedents, and implications for social development. Developmental Psychology, 36 (2), 220-232. http://dx.doi.org/10.1037/0012-1649.36.2.220

Kochanska, G., Murray, K. T. Jacques, T. Y. Koenig, A. L. \& Vandegeest, K. A.. (1996). Inhibitory control in young children and its role in emerging internalization. Child Development, 67 (2), 490-507. https://doi.org/10.1111/j.1467-8624.1996.tb01747.x

Kopp, C. (1982). Antecedents of self-regulation: A developmental perspective. Developmental Psychology, 18 (2), 199-214. http:// dx.doi.org/10.1037/0012-1649.18.2.199

Lengua, L. J., Sandler, I. N. West, S. G. Wolchik, S. A. \& Curran, P. J.. (1999). Emotionality and self-regulation, threat appraisal, and coping in children of divorce. Development and Psychopathology, 11, 15-37.

Madigan, S., Bakermans-Kranenburg, M., van Ijzendoorn, M., Moran, G., Pederson, D. \& Benoit, D. (2006). Unresolved states of mind, anomalous parental behavior, and disorganized attachment; A review and meta analysis of a transmission gap. Attachment \& Human Development, 8, 89-111. https://doi.org/10.1080/14616730600774458 
Malakoff, M. E., Underhill, M. \& Zigler, E. (1998). Influence of inner-city environment and Head Start experience on effectance motivation. American Journal of Orthopsychiatry, 68 (4), 630-638. https://doi.org/10.1037/h0080371

Mangelsdorf, S.C., Shapiro, J. \& Marzolf, D. (1995). Developmental and temperemental differences in emotion regulation in infancy. Child Development, 66 (6), 1817-1828. https://doi.org/10.1111/j.1467-8624.1995.tb00967.x

Mattanah, J. F., Pratt, M. W., Cowan, P. A. \& Cowan, C. P. (2005). Authoritative parenting, parental scaffolding of long-division mathematics, and children's academic competence in fourth grade. Journal of Applied Developmental Psychology, 26 (1), 85-106. https://doi.org/10.1016/j.appdev.2004.10.007

McClelland, M. M., Cameron, C. E., Conor, C.M., Farris, C. L., Jewkes, A. M. ve Morrison, F.J. (2007). Links between behavioral regulation and preschoolers' literacy, vocabulary, and math skills.Developmental Psychology, 43(4), 947-959.

Metin, i. (2010). The effects of dispositional anger, effortful control and maternal responsiveness on Turkish preschoolers' emotion regulation. Unpublished master thesis, Koç University Social Sciences Institude, İstanbul.

Meins, E., Fernyhough, C. \& Russell, J. (1998). Security of attachment as a predictor of mentalising abilities: A longitudinal study. Social Development, 7 (1), 1-24. https://doi.org/10.1111/1467-9507.00047

Moilanen, K. L., Shaw, D. S. Dishion, T. J. Gardner, F. \& Wilson, M.. (2010). Predictors of longitudinal growth in inhibitory control in early childhood. Social Development 19 (2), 326-347. https://doi.org/10.1111/j.1467-9507.2009.00536.x

Morris, A. S., Silk, J. S. Steinberg, L. Myers, S. S. \& Robinson, L. R.. (2007). The role of the family context in the development of emotion regulation. Social Development, 16 (2), 361-388. https://doi.org/10.1111/j.1467-9507.2007.00389.x

Moss, E. \& St-Laurent, D. (2001). Attachment at school age and academic performance. Developmental Psychology, 37(6), 863874. http://dx.doi.org/10.1037/0012-1649.37.6.863

OECD. (2011). Retrieved from http://www.oecd.org/social/database. htm\#labour_market

O'Connor, E. \& McCartney, K. (2007). Attachment and cognitive skills: An investigation of mediating mechanisms. Journal of Applied Developmental Psychology, 28 (5-6), 458-476. https://doi.org/10.1016/j.appdev.2007.06.007

Olson, S. L., Bates, J. E., Sandy, J. M. \& Schilling, E. M.. (2002). Early developmental precursors of impulsive and inattentive behavior: From infancy to middle childhood. Journal of Child Psychology and Psychiatry, 43 (4), 435-447. https://doi. org/10.1111/1469-7610.00035

Paterson, G., \& Sanson, A. (1999). The association of behavioral adjustment to temperament, parenting and family characteristics among 5-year-old children. Social Development, 8(3), 293-309.

Pearson, K. M. (2013). Attachment and Self Regulation in Preschool Age Children. Unpublished master thesis, University of Rhode Island.

Pino Pasternak, D. \& Whitebread, D. (2010). The role of parenting in children's self regulated learning. Educational Research Review, 5 (3), 220-242. https://doi.org/10.1016/j.edurev.2010.07.001

Pratt, M. W., Green, D., MacVicar, J. \& Bountrogianni, M. (1992). The mathematical parent: Parental scaffolding, parenting style, and learning outcomes in long-division mathematics homework. Journal of Applied Developmental Psychology, 13 (1), 17-34. https://doi.org/10.1016/0193-3973(92)90003-Z

Pratt, M. W., Kerig, P., Cowan, P. A. \& Cowan, C. P. (1988). Mothers and fathers teaching 3 year-olds: Authoritative parenting and adult scaffolding of young children's learning. Developmental Psychology, 24 (6), 832-839. http://dx.doi.org/10.1037/00121649.24.6.832

Ponitz, C. E. C., McClelland, M. M., Jewkes, A. M., Connor, C. M., Farris, C. L. \& Morrison, F. J. (2008). Touch your toes! Developing a direct measure of behavioral regulation in early childhood. Early childhood Research Quarterly, 23 (2), 141-158. https:// doi.org/10.1016/j.ecresq.2007.01.004

Power, T. G. (2004). Stress and coping in childhood: The parents' role. Parenting: Science and Practice, 4, $271-317$.

Ramani, G. B., Brownell, C. A. \& Campbell, S. B. (2010). Positive and negative peer interaction in 3-and 4-year-olds in relation to regulation and dysregulation. The Journal of Genetic Psychology, 171 (3), 218-250. https://doi.org/10.1080/00221320903300353

Rothbart, M. K., Ahadi, S. A. \& Evans, D. E. (2000). Temperament and personality: Origins and outcomes. Journal of Personality and Social Psychology, 78 (1), 122-135.

Schraw, G., Crippen, K. \& Hartley, K. (2006). Promoting self-regulation in science education: metacognition as part of a broader perspective on learning. Research in Science Education, 36 (1-2), 111-139. https://doi.org/10.1007/s11165-005-3917-8

Schunk, D. H. (2001). Social cognitive theory and self-regulated learning. In Self-regulated learning and academic achievement: Theoretical perspectives, Barry J. Zimmerman \& Dale H. Schunk, (2.edi, p.125-151). Manwah, NJ: Lawrence Erlbaum.

Schunk, D. H. \& Zimmerman, B. J. (1997). Social origins of self-regulatory competence. Educational Psychologist, 32 (4), $195-208$. https://doi.org/10.1207/s15326985ep3204_1

Siegel, D. J. (2001). Toward an interpersonal neurobiology of the developing mind:

Attachment relationships, "Mindsight" and neural integration. Infant Mental Health Journal, 22 (1-2), 67-94. https://doi.org/10.1002/1097-035 5(200101/04)22:1<67::AID-IMHJ3>3.0.CO;2-G 
Simonds, J., Kieras, J. E. Rueda, M. R. \& Rothbart, M. K. (2007). Effortful control, executive attention, and emotional regulation in 7-10-year-old children. Cognitive Development, 22 (4), 474-488. https://doi.org/10.1016/j.cogdev.2007.08.009

Sözügeçer, Z. (2011). Çocuklardaki davranış problemlerinin, bağlanma stilleri, aile işlevleri ve anne kabul algıları açısından incelenmesi [Examining the behavior problems in children in terms of attachment security, family functions and perceptions of acceptance/rejection of the mother]. (Unpublished master thesis), İstanbul University, İstanbul, Turkey.

Sturge-Apple, M. L., Davies, P. T., Martin, M. J., Cicchetti, D. \& Hentges, R. F. (2012). An examination of the impact of harsh parenting contexts on children's adaptation within an evolutionary framework. Developmental Psychology, 48 (3), 791-805. http:// dx.doi.org/10.1037/a0026908

Szewczyk-Sokolowski, M., Bost, K. K. \& Wainwright, A. B. (2005). Attachment, temperament, and preschool chidren's peer acceptance. Social Development, 14 (3), 379-397. https://doi.org/10.1111/j.1467-9507.2005.00307.x

Taylor, Z.E., Eisenberg, N. Spinrad, T. L. \& Widaman, K. F. (2013). Longitudinal relations of intrusive parenting and effortful control to ego-resiliency during early childhood. Child Development, 84 (4), 1145-1151. https://doi.org/10.1111/cdev.12054

Turner, L. A. \& Johnson, B.. (2003). A model of mastery motivation for at-risk preschoolers. Journal of Educational Psychology, 95 (3), 495-505.

Uluç, S. \& Öktem, F. (2009). Okul Öncesi Çocuklarda Güvenli Yer Senaryolarının Değerlendirilmesi [The investigation of secure base scripts of preschool children]. Turkish Journal of Psychology, 24, 69-83.

Uluç, S. \& Öktem, F.. (2010). Okul öncesi çocuklarda güvenli yer senaryoları ve kişilerarası beklentiler arasındaki ilişkiler [Relations between secure base scripts and interpersonal expectation of preschool children]. Turkish Journal of Child and Adolescent Mental Health, 17, 139-147.

Ural, O., Güven, G. Sezer, T. Efe-Azkeskin, K. \& Yılmaz, E. (2015). Okul öncesi dönemdeki çocukların bağlanma biçimleri ile sosyal yetkinlik ve duygu düzenleme becerileri arasındaki ilişkinin incelenmesi [The investigation of the relation between attachment styles, social competence and emotion regulation skills of preschool children]. Hacettepe University Faculty of Health Sciences Journal, 1, 589-598.

van IJzendoorn, M., Dijkstra, J. \& Bus, A. G. (1995). Attachment, intelligence, and language: A meta-analysis. Social Development, 4 (2), 115-128. https://doi.org/10.1111/j.1467-9507.1995.tb00055.x

Vaough, B., Egeland, B., Srouge, A. \& Waters, E. (1979). Individual differences in infant-mother attachment at twelve and eighteen months: Stability and change in families under stress. Child Development, 50 (4), 971-975. https://doi.org/10.2307/1129321

Wertsch, J. V., McNamee, G. D. McLane, J. B. \& Budwig, N. A. (1980). The adult-child dyad as a problem-solving system. Child Development, 51 (4), 1215-1221. https://doi.org/10.2307/1129563

West, K.K., Brittany, L.M. \& Kerns, K. A. (2013). Mother-child attachment and cognitive performance in middle childhood: An examination of mediating mechanisms. Early Childhood Research Quarterly, 28 (2), 259-270. https://doi.org/10.1016/j.ecresq.2012.07.005

Whitebread, D., Coltman, P. Pasternak, D. P., Sangster, C. Grau, V., Bingham, S. S., Almeqdad, O. \& Demetriou, D. (2009). The development of two observational tools for assessing metacognition and self-regulated learning in young children. Metacognition Learning, 4 (1), 63-85. https://doi.org/10.1007/s11409-008-9033-1

Wood, D., Bruner, J. \& Ross, G. (1976). The role of tutoring in problem solving. Journal of Child Psychology and Psychiatry, 17 (2), 89-100. https://doi.org/10.1111/j.1469-7610.1976.tb00381.x

Yağmurlu, B., \& Sanson, A. (2009). The role of child temperament, parenting and culture in the development of prosocial behaviors. Australian Journal of Psychology, 61(2), 77-88. http://doi.or/10.1080/00049530802001338

Zhou, Q., Eisenberg, N. Wang, Y. \& Reiser, M. (2004). Chinese children's effortful control and dispositional anger/frustration: Relations to parenting styles and children's social functioning. Developmental Psychology, 40 (3), 352-366. http://dx.doi. org/10.1037/0012-1649.40.3.352 